UDC: 005.52:640.412(497.11) 330.143

\title{
Antecedents of Hotel Profitability: Empirical Evidence from Belgrade
}

DOI: 10.7595/management.fon.2016.0031

\begin{abstract}
Tourism and hospitality have received an immense attention from scholars, policy holders, decision makers and other important stakeholders in Belgrade, a main tourist destination of Serbia. The aim of this paper is to determine the main drivers of profit margins in the hotel sector in Belgrade. A particular aim is to explore the effects of variables - size, market concentration, and market share and customer satisfaction - on hotel profit margins. The study analyzed the secondary reliable sources. The data were analyzed with correlations and regressions. The results indicate that customer perception is a paramount factor driving the financial performance of hotels. These findings could be useful to scholars and practitioners interested in business performances of Belgrade hotels.
\end{abstract}

Keywords: profitability drivers, profit margin, hotels, customer perception, Belgrade

\section{Introduction}

Tourism and hospitality industry has been highly positioned on the agenda of both policy holders (Milosavljević, Milanović, Benković, 2015), and decision makers (Filipović, Jovanović \& Cicvarić Kostić, 2013; Krstić, Radivojević \& Stanišić, 2016) in Serbia. The rationale for this is the high impact of tourism on the economic development of the Belgrade region and the economy as a whole. Academic publications almost equally intensively elaborate on the importance of tourism, the sources of development, the features of processes in the industry and its economic effects (Mulec\& Wise, 2013). From a micro-perspective, a broad body of knowledge has been developing in the area of hotel performance measurement (Sainaghi, 2013; McManus, 2013). Nevertheless, a paucity of scholarly contributions has been related to the examination of origins of hotel financial performances. This particularly refers to the Belgrade's hotel sector.

This study aims to fill the aforementioned lacuna in the scholarly research. The aim is to analyze different drivers of profitability, such as size, market concentration, market share and customer perception, that affect the profitability of hotels in Belgrade. In particular, the study aims to test the effects of these factors on the hotels' financial performance.

Hitherto, a myriad of studies were focused on elaborating on hotel financial success drivers (Ganchev, 2000; O'Neill \& Mattila, 2006; Dalci, Tanis \& Kosan, 2010). Further on, Ben Aissa\&Goaied (2016) empirically tested the main determinants of 27 Tunisian hotels. Lado-Sestayo et al. (2016) conducted a study encompassing nearly 9000 hotels in Spain to test the impact of location on profitability in the Spanish hotel sector. Nevertheless, the originality of this study is based on two important pillars. First, to the best of authors' knowledge, the study is unique in this geographical region. Some aspects of the Belgrade hotel sector, such as the change in offer, have been discussed in the extant literature (Šimičević\&Štetić, 2015), but none of the studies dealt with the profitability of the sector. Second, the study is unique in the developed set of indicators selected as the main drivers of profitability

The remainder of the manuscript is organized as follows. Section 2 deals with theoretical background. Particular emphasis is given to the business case of the hotel industry in Belgrade. Section 3 elaborates on the methodology used in the study. Section 4 depicts the results and discusses the main findings. Section 5 provides concluding remarks, dealing with the resume of key findings, managerial and other implications, limitations and further recommendations. 


\section{Theoretical Background}

\subsection{Profitability Drivers in Hotel Industry}

Profitability drivers are frequently elaborated in the extant literature. Ever since the pioneering attempts of Kotas (1982), Sheldon (1983) and Croston (1995) research has been examining various determinants of profitability, thus striving to find the best methodology for the analysis of financial operations and appropriate business strategy. According to the nature of profitability drivers, several streams of scholarly publications are particularly important in this field.

The first stream are the publications that emphasize the importance of market power, location and concentration on business performances of hotels. For instance, Pan (2005) investigated the effects of market structure on hotel profitability and found significant positive effects of the international hotels' location on profitability. Singh \& Dev (2015) have analyzed hotels as winners and losers in the aftermath of the recession, suggesting that marketing expenses play an important role in financial success. Lado-Sestayo et al. (2015) explored the influence of location, market power and other factors to the profitability of the Spanish hotel sector. They find that profitability depends largely on the market structure and the level of demand of the tourist destination. Accordingly, this study hypothesizes that [H1a]: Location has a positive effect on profitability and [H1b]: Market power has a positive effect on profitability.

The second stream are the papers dealing with operational and financial efficiency. Zeglat (2008) finds that profitability is positively influenced by sales growth, as a consequence of customer retention, and negatively influenced by premium price by analyzing the UK hotel sector. Chiu and Huang (2011) analyzed the effects of occupancy rate and operational efficiency on profitability of Taiwanese hotels and found that occupancy rate and increase in sales are not the best way to increase financial performance. This is not in line with the main findings of O'Neill \& Ma. Instead, they suggest an optimal occupancy rate and focus on operational efficiency. Another study from the same country deals with the effects of service quality, and indicates that, for instance, food and beverage quality has non-linear relationship with profitability (Chen \& Lin, 2012). In the example of the Croatian hotel industry, Škuflić\&Mlinarić (2015) find that size, concentration, liquidity, solvency and productivity significantly affect hotel profitability. Based on the aforementioned review of literature, this study hypothesizes that [H2a]: Size has a positive effect on profitability, [H2b]: Hotel capacity has a positive effect on profitability, [H2c]: Hotel category has a positive effect on profitability, and [H2d]: Financial leverage has a negative effect on profitability.

The third stream are studies examining the role of online hotel presence and the effects of social media on hotel performance. The results are to some extent adverse. For instance, Neirotti, Raguseo \&Paolucci (2016) find that the increasing importance of user-generated reviews in online communities for tourists is "shifting hotel competition from unit profit margin to volumes and to higher room occupancy rates, with online retailers capturing most of the value created in online transactions through social media features and with a limited effect brought on net profitability". Using a more sophisticated approach of neural networks, Phillips et al. (2015) study the interactive effects of online reviews on the determinants of Swiss hotel performance, finding a positive effect of four nodes to a hotel performance. Following this stream of research, this study hypothesizes that [H3a]: Social reach has a positive effect on profitability, and [H3b]: Customer satisfaction has a positive effect on hotel profitability.

Some studies do not fit into this three-stream pattern. Certain studies address macroeconomic features and their influence over the profitability (Pan, 2005). On the other hand, a broad body of evidence takes into consideration the human factor as an important pillar of profitability. For instance, Morey \&Ditman (1995) examined the effects of general managers' efficiency on the hotel profitability. Finally, profitability is examined through the prism of long term yields generated from the adequate customer profitability analysis (Noone\& Griffin, 1999).

\subsection{A Business Case for the Hotel Sector in Belgrade}

Belgrade accounts for more than a third of all tourist capacities of Serbia, which puts a spotlight on the importance of this industry for the total economic output of the country. Belgrade is the most important tourist destination in Serbia. The following figures illustrate the portion of total arrivals and nights of tourists in Serbia and in Belgrade in particular (RZS, 2015). 


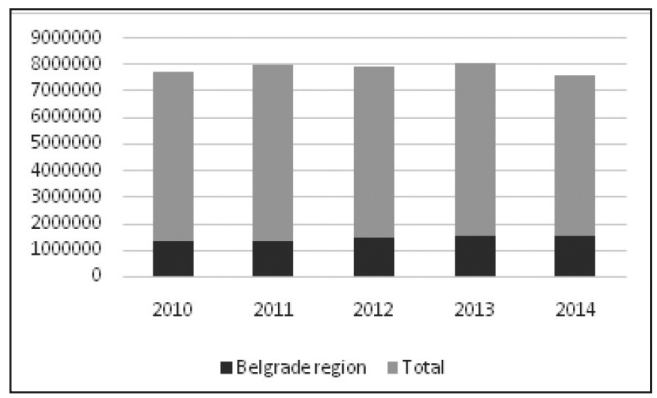

Figure 1: Total arrivals of tourists in Serbia and in Belgrade

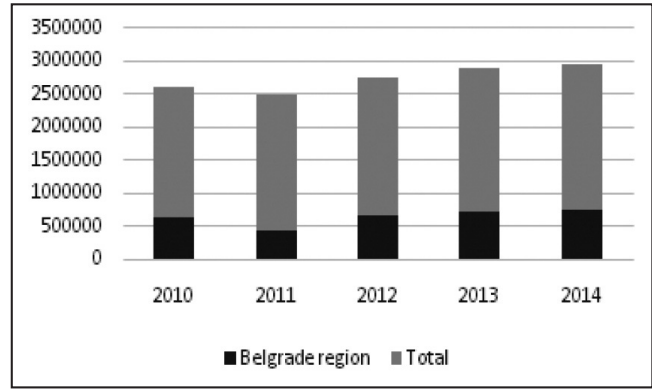

Figure 2: Total nights of tourists in Serbia and in Belgrade

According to Horwath (2015), internationalization of the demand profile is evident, followed by permanent increase in the relative share of foreign hotel overnights in total overnights. This study points out the international demand as a primary source of demand for Belgrade hotels, with annual growth rate of 10\% (2009-2014).

\section{Methodology}

\subsection{Variables}

For the dependent variable - hotel profitability, we used profit margins following Lado-Sestayo et al. (2016). As regards the independent variables, their indicators, calculations and rationale for the use are given in the following table.

Table 1: Variables, indicators, calculations and rationale for their use

\begin{tabular}{|l|l|l|l|}
\hline Variable & Indicator & Calculation & Rationale \\
\hline Location & $\begin{array}{l}\text { Distance from three focal } \\
\text { points - city center, central } \\
\text { bus station and airport }\end{array}$ & (Dcen+Dbus+Dair)/3 & Developed by authors \\
based) & Size & $\begin{array}{l}\text { Net revenue for a hotel/Total } \\
\text { revenue for industry }\end{array}$ & Based on Chen \& Chiu (2014) \\
\hline Market power & Natural logarithm of hotel assets & $\begin{array}{l}\text { Rewarded from Demsetz (1974) and } \\
\text { Lado-Sestayo et al. (2016) }\end{array}$ \\
\hline Financial structure & Financial leverage & Liabilities/Equity & $\begin{array}{l}\text { Based on Milosavljevic, Milanovic \& } \\
\text { Benkovic (2013) }\end{array}$ \\
\hline Social reach & Social media reach & No of Facebook page likes & $\begin{array}{l}\text { Based on Virginia Phelan, Chen \& } \\
\text { Haney (2013) }\end{array}$ \\
\hline Customer satisfaction & Aggregate hotel ranking & Booking.com ranking & $\begin{array}{l}\text { Based on Noone, Kimes \& Renaghan } \\
\text { (2003) }\end{array}$ \\
\hline Word-of-mouth & Net promoter score & $\begin{array}{l}\text { Highest to lowest ranks of } \\
\text { customers }\end{array}$ & According to Grisaffe (2007) \\
\hline Margins & Net margin & Net income/Revenue & Developed by authors \\
\hline Capacity & Total accommodation share & $\begin{array}{l}\text { No of beds of a hotel/No of beds } \\
\text { of all hotels }\end{array}$ & Based on Pan (2007) \\
\hline Hotel category & Category of a hotel & No of stars & Based on Kim \& Kim (2005) \\
\hline
\end{tabular}




\subsection{Sampling and Data Collection}

The study examined 42 hotels located in the city area of Belgrade. The sample was randomly generated from the total of 530 hotels. The study is based on secondary data collected from different reliable sources. Financial data (assets, operating revenues, operating income, net income, liabilities, equity, average number of employees, foundation date) were retrieved from the Serbian Agency for Business Registers. These data refer to the year 2014. The data on the location and the distance from three aforementioned focal points were generated from Google Maps. The data on customer satisfaction were retrieved from the booking.com online service for hotel bookings and rankings, where the scores from 1 to 10 assigned by hotel customers were used as an input. Social media reach as an important variable for this study was analyzed through the usage of Facebook. The data on number of hotel Facebook page likes and scores from 1 to 5 awarded by page visitors were collected. The data on number of available beds and rooms were retrieved from hotels' official websites and the Tourist organization of Belgrade. Hotel ranking, reputation and luxury were measured by the number of stars retrieved from the Tourist organization of Belgrade. Foundation dates were collected from hotel official websites.

\subsection{Data Analysis}

After filtering the collected data, the lack of data on booking.com scores for several hotels was noticed. The Orange Canvas software was used to replace the missing values with the average value of the booking.com scores available for other hotels. Furthermore, Orange algorithm recognized a few outliers and excluded them from database before proceeding with analysis. Due to perceived anomalies, the data on hotels Constantine The Great and Zepter were also excluded. Finally, the statistical analysis of refined data was conducted through SPSS software.

\section{Results and Discussion}

\subsection{Descriptive Statistics}

The following table displays the descriptive statistics: means and standard deviation for 37 observed hotels.

Table 2: Descriptive statistics

\begin{tabular}{|l|l|l|}
\hline Variable & Mean & Std. Deviation \\
\hline Profit margin (\%) & 1.02711 & 31.693632 \\
\hline Average distance (km) & 8.67805 & 3.206473 \\
\hline Market share (\%) & 2.30195 & 2.296098 \\
\hline LN(assets) (\#) & 19.77232 & 1.521281 \\
\hline Financial leverage (\#) & 8.144443 & 92.881617 \\
\hline No of Facebook likes (\#) & 3812.19 & 6449.961 \\
\hline Average score on Booking (\#) & 8.308 & .8855 \\
\hline Net Promoter Score (\%) & 55.23511 & 28.186677 \\
\hline Net margin (\%) & -11.57597 & 48.096229 \\
\hline Accommodation capacity (\%) & 2.00535 & 1.499629 \\
\hline Number of stars (\#) & 3.68 & .626 \\
\hline
\end{tabular}

\subsection{Hypotheses Testing}

In order to test the hypotheses the study employed the correlation analysis (Pearson moment two-tailed correlation) and the multiple regression. The correlation analysis is performed as a preliminary analysis in order to assess the strength of relationships among the variables in the study. The results of the correlation analysis are displayed in the following table. The correlation coefficients reflected low to medium values and therefore did not indicate a potential multicollinearity among variables. 
Table 3: Correlation matrix

\begin{tabular}{|c|c|c|c|c|c|c|c|c|c|c|c|}
\hline & 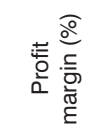 & 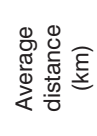 & 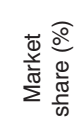 & 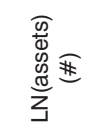 & 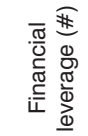 & 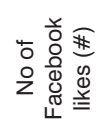 & 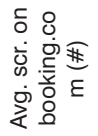 & 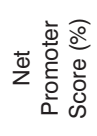 & 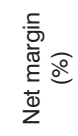 & 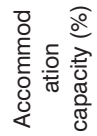 & 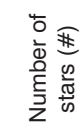 \\
\hline Profit margin (\%) & 1.000 & .040 & .212 & $-.013^{\star \star}$ & $.006^{\star \star}$ & .102 & .788 & .367 & .634 & .082 & .438 \\
\hline $\begin{array}{l}\text { Average } \\
\text { distance }(\mathrm{km})\end{array}$ & $.040^{\star}$ & 1.000 & $.008^{\star \star}$ & $-.271^{\star \star}$ & $-.080^{\star \star}$ & $-.236^{\star \star}$ & $.037^{\star}$ & .284 & $.024^{*}$ & $-.152^{\star \star}$ & $-.151^{* *}$ \\
\hline $\begin{array}{l}\text { Market share } \\
(\%)\end{array}$ & .212 & .008 & 1.000 & .556 & .023 & .389 & .277 & $.011^{\star}$ & .107 & .338 & .400 \\
\hline LN(assets) (\#) & $-.013^{\star \star}$ & $-.271^{\star \star}$ & .556 & 1.000 & $-.260 \star \star$ & .307 & .138 & $-.217^{\star \star}$ & .073 & .410 & .445 \\
\hline $\begin{array}{l}\text { Financial } \\
\text { leverage }(\#)\end{array}$ & $.006^{\star \star}$ & $-.080^{\star \star}$ & $.023^{\star}$ & $-.260^{\star *}$ & 1.000 & .225 & .051 & $.014^{\star}$ & .201 & $.001^{\star *}$ & $-.194^{\star \star}$ \\
\hline $\begin{array}{l}\text { No of Facebook } \\
\text { likes (\#) }\end{array}$ & .102 & $-.236^{\star \star}$ & .389 & .307 & .225 & 1.000 & .281 & $-.304^{\star \star}$ & .143 & .300 & .320 \\
\hline $\begin{array}{l}\text { Avg.scr. on } \\
\text { Booking (\#) }\end{array}$ & .788 & $.037^{\star}$ & .277 & .38 & .051 & .281 & 1.000 & .204 & .535 & $.009^{\star \star}$ & .561 \\
\hline $\begin{array}{l}\text { Net Promoter } \\
\text { Score (\%) }\end{array}$ & .367 & .284 & $.014^{*}$ & $-.217^{\star \star}$ & $.014^{*}$ & $-.304^{\star *}$ & .204 & 1.000 & .501 & $-.116^{\star \star}$ & $-.036^{\star *}$ \\
\hline Net margin (\%) & .634 & $.024^{\star}$ & .107 & $-.073^{\star \star}$ & .201 & .143 & .535 & .501 & 1.000 & .149 & .126 \\
\hline $\begin{array}{l}\text { Accomm. } \\
\text { capacity (\%) }\end{array}$ & .082 & $-.152^{\star \star}$ & .338 & .410 & $.001^{\star *}$ & .300 & $.009^{\star \star}$ & $-.116^{\star \star}$ & .149 & 1.000 & .169 \\
\hline $\begin{array}{l}\text { Number of stars } \\
(\#)\end{array}$ & .438 & $-.151^{\star \star}$ & .400 & .445 & $-.194^{\star \star}$ & .320 & .561 & $.036^{\star}$ & .126 & $.0169^{*}$ & 1.000 \\
\hline
\end{tabular}

The correlation matrix shows that the highest correlation exists on the average score on Booking to profit margin. The results of employed t-test underline this variable as the only statistically significant variable for profit margin. The next variable according to the value of correlation coefficient is the net margin, followed by the number of stars, implying that hotels with higher ranking, reputation and luxury generate a higher profit margin. The analysis of correlation between independent variables shows that the most correlated variables are the number of stars and the average score on Booking, with the value of correlation coefficient 0.634 . The correlation of LN (assets) to market share (0.556) confirms that hotels that achieve economies of scale take greater market share.

The model was tested with regression analysis (results are displayed in the table below).

Table 4: Regression model and ANOVA

\begin{tabular}{|c|c|c|c|c|c|c|}
\hline \multirow{2}{*}{\multicolumn{2}{|c|}{ Regression model }} & \multicolumn{2}{|c|}{ Unstandardized Coefficients } & \multirow{2}{*}{$\begin{array}{l}\text { Standardized } \\
\text { Coefficients }\end{array}$} & \multirow[b]{2}{*}{$\mathrm{t}$} & \multirow[b]{2}{*}{ Sig. } \\
\hline & & $\mathrm{B}$ & Std. Error & & & \\
\hline \multirow[t]{11}{*}{1} & Constant & -112.747 & 70.341 & & -1.603 & .121 \\
\hline & Average distance $(\mathrm{km})$ & -.729 & 1.128 & -.074 & -.646 & .524 \\
\hline & Market share (\%) & 1.490 & 1.900 & .108 & .784 & .440 \\
\hline & LN(assets) (\#) & -4.739 & 3.094 & -.227 & -1.531 & .138 \\
\hline & Financial leverage (\#) & -.032 & .040 & -.095 & -.814 & .423 \\
\hline & No of Facebook likes (\#) & -0.001 & .001 & -.126 & -.964 & .344 \\
\hline & Avg. scr. on booking.com (\#) & 22.364 & 5.538 & .625 & 4.038 & .000 \\
\hline & Net Promoter Score (\%) & .074 & .153 & .066 & .484 & .632 \\
\hline & Net margin (\%) & .163 & .099 & .247 & 1.639 & .113 \\
\hline & Accommodation capacity (\%) & 2.382 & 2.508 & .113 & .950 & .351 \\
\hline & Number of stars (\#) & 5.496 & 7.284 & .109 & .754 & .457 \\
\hline \multicolumn{7}{|c|}{ Dependent Variable: Profit margin (\%) } \\
\hline \multicolumn{2}{|c|}{ ANOVA } & $\begin{array}{l}\text { Sum } \\
\text { Squares }\end{array}$ & df & Mean Square & $\mathrm{F}$ & Sig. \\
\hline & $\begin{array}{l}\text { Regression } \\
\text { Residual } \\
\text { Total }\end{array}$ & $\begin{array}{l}26723.265 \\
9438.243 \\
36161.507\end{array}$ & $\begin{array}{l}10 \\
26 \\
36\end{array}$ & $\begin{array}{l}2672.326 \\
363.009\end{array}$ & 7.362 & $.000^{\mathrm{b}}$ \\
\hline \multicolumn{7}{|c|}{$\begin{array}{l}\text { Dependent Variable: Profit margin (\%) } \\
\text { Predictors (Constant), Number of stars (\#), Net Promoter Score (\%), Financial leverage (\#), Accommodation capacity (\%) } \\
\text { Average distance }(\mathrm{km}) \text {, Market share (\%), Net margin (\%), No of Facebook likes (\#), LN (assets) (\#), Avg.scr. or } \\
\text { booking.com }(\#)\end{array}$} \\
\hline
\end{tabular}

As for the overall model, the results $(F=7.362, \mathrm{Sig}=.000)$ indicate that the model is statistically significant. The individual results and hypotheses tests are further elaborated as follows.

Average distance. The initial hypothesis: There is a negative relationship between average distance and profit margin. The average distance variable should influence the decision of tourist/customer to choose 
particular hotel according to the amount of time needed to get to the city's most important focal points (city center, central bus station and airport). Hotels with smaller average distance have higher occupancy rates, which could lead to higher profit margin. The result of t-test $t=-0,646$ with $\operatorname{Sig}=0,524$ indicates that this variable is not statistically significant for profit margin.

Market share. The initial hypothesis: There is a positive relationship between market share and profit margin. The assumption is that hotels with higher market share are more recognizable by the tourists, which can increase their profit margins. However, the result of the t-test $t=-0,784$ with $\operatorname{Sig}=0,440$ indicates that market share is not statistically significant for profit margin.

LN (assets). The initial hypothesis: There is a positive relationship between hotel size and profit margin. Hotels with a higher value of LN (assets) achieve economies of scale and reduce expenses, which increases their profit margins. The result of the t-test test $t=-1,531$ with $\operatorname{Sig}=0,138$ indicates that this variable is not statistically significant for profit margin.

Financial Leverage. The initial hypothesis: There is a negative relationship between financial leverage and profit margin. It is assumed that hotels with lower financial leverage are more efficient, which can lead to higher profit margins. The result of the t-test $t=-0,814$ with $\operatorname{Sig}=0,423$ indicates that this variable is not statistically significant for profit margin.

Social media reach. The initial hypothesis: There is a positive relationship between the number of Facebook likes and profit margin. The number of likes on social networks indicates to what extent a particular hotel is popular among customers. A higher number of likes and followers increases the potential of a hotel to be chosen by tourists as a place to stay. Consequently, this can lead to higher profit margins. The result of the t-test $t=-0,646$ with Sig $=0,524$ shows that this variable is not statistically significant for profit margin.

Aggregate hotel ranking. The initial hypothesis: There is a positive relationship between the average score on booking.com and profit margin. A higher average score shows higher popularity among tourists and higher customer satisfaction and potentially attracts more hotel guests, which can consequently increase profit margins. However, the result of the t-test $t=-4,038$ with $\mathrm{Sig}=0,000$ indicates that this variable is statistically significant for profit margin.

Net Promoter Score: The initial hypothesis: There is a positive relationship between the Net Promoting Score and profit margin. The Net Promoting Score is a marketing metrics that indirectly shows a word-of-mouth effect achieved by a certain hotel. A higher score indicates a significant difference between respondents who recommend certain hotel and those who would not recommend it. This can lead to higher profit margins, but the result of the t-test $t=-0,484$ with $\operatorname{Sig}=0,632$ shows that the Net Promoting Score is not statistically significant for profit margin.

Net margin. The initial hypothesis: There is a positive relationship between the net margin and the profit margin. According to the result of the t-test $t=-1,639$ with $S i g=0,113$, this variable is not statistically significant for profit margin.

Accommodation capacity: The initial hypothesis: There is a positive relationship between accommodation capacity and profit margin. Hotels with high accommodation capacity could take advantage of economies of scale and consequently increase profit margin. The result of the t-test $t=-0,950$ with $\operatorname{Sig}=0,351$ indicates that accommodation capacity is not statistically significant for profit margin.

Category of hotel. The initial hypothesis: There is a positive relationship between the category of hotel and the profit margin. The number of stars reflects a hotel's ranking, reputation and luxury. Hotels with high ranking should attract more tourists and consequently increase profit margin. According to the result of the t-test $t=-0,754$ with $\operatorname{Sig}=0,457$, this variable is not statistically significant for profit margin. 
This paper aimed to determine the main drivers of profit margins of the Belgrade hotel sector. As the results indicate, the main profit margin driver is the previous customer satisfaction with hotel services. As for the contribution to the theory and practice of hotel management, this study has twofold implications. First, the study contributes to the practice of hotel management as it empirically confirms that consumers and their opinions make the ultimate factor that adds financial value to a hotel sector. Accordingly, the efforts of decision makers in hotels should be placed to the online reputation creation. As the results of statistical analysis indicate, the only variable that is statistically significant for profit margin is the average score on booking.com, so it is recommended that efforts should be made to increase the rankings on booking.com. The average score on booking.com is composed by the following elements: cleanliness, location, staff, free Wi-Fi, comfort, additional facilities, and price-quality relation. Hotels should strive to set higher hygiene standards, improve wireless network performance, and to employ HR training and development programs in the field of customer relationship management. Significant attention should be paid to tracking and in-depth analysis of customers comments on websites booking.com and tripadvisor.com, and official Facebook pages. This analysis provides the information on the level of customer satisfaction and the necessity of additional facilities and service provision. A timely identification of negative customer feedback enables hotels to fix their internal processes in order to prevent a negative impact on their image and reputation. This is why these comments should be carefully tracked and responded to by a professional, regardless whether they have a positive or a negative connotation.

Second, the paper has implications for other researchers in the field. Although the study did not cover all possible drivers of profit margins, it is important to path the way for further research in the area of hospitality industry. The study has some major limitations, both fundamental and technical. Fundamental limitations are linked to the set of variables used in the study. Accordingly, a recommendation for further research is to encompass a wider set of variables and statistically tested and refined indicators. Technical limitations are based on the sample size, time frame, and the techniques used for the analysis. The sample size is rather small, and this study should be viewed as an ongoing project. This study is cross-sectional and based on the data from 2014. Further studies should apply time series and capture the evolutionary features of the hotel profitability in Belgrade. Finally, as all the other quantitative studies, this study has some technical flaws. Further studies should conceptualize on qualitative aspects of the topic covered and include a mixed-method approach in the analysis. Accordingly, the success on this intensively competitive market in the digital era should not and cannot be based solely on improvements of offline aspects of the hotel industry. Hotels must focus their efforts on improving online appearance and digital reputation management.

\section{REFERENCES}

[1] Aissa, S. B., \&Goaied, M. (2016). Determinants of Tunisian hotel profitability: The role of managerial efficiency. Tourism Management, 52, 478-487.

[2] Chen, C. M., \& Chiu, H. H. (2014). Re-examining the market structure effects on hotel performance using market share inequality.International Journal of Hospitality Management, 41, 63-66.

[3] Chen, C. M., \& Lin, Y. C. (2012). Does better service induce higher profitability? Evidence from Taiwanese Hospitality Industry. International Journal of Hospitality Management, 31(4), 1330-1332.

[4] Chiu, Y. H., \& Huang, C. W. (2011). Evaluating the optimal occupancy rate, operational efficiency, and profitability efficiency of Taiwan's international tourist hotels. The Service Industries Journal, 31(13), 21452162.

[5] Croston, F. (1995). Hotel profitability: Critical success factors. Accounting and finance for the international hospitality industry, 295-314.

[6] Dalci, I., Tanis, V., \& Kosan, L. (2010). Customer profitability analysis with time-driven activity-based costing: a case study in a hotel. International Journal of Contemporary Hospitality Management, 22(5), 609637.

[7] Filipovic, V., Jovanovic, D., \& Cicvaric Kostic, S. (2013). Attracting tourists to a shopping centre.Management, (66), 15-18. DOI:10.7595/management.fon.2012.0037

[8] Ganchev, O. (2000). Applying value drivers to hotel valuation. Cornell Hotel and Restaurant Administration Quarterly, 41(5), 78-89.

[9] Grisaffe, D. B. (2007). Questions about the ultimate question: conceptual considerations in evaluating Reichheld's net promoter score (NPS).Journal of Consumer Satisfaction, Dissatisfaction and Complaining Behavior,20, 36. 
[10] Horwath (2015). Special market report, Issue 53: Serbia, available at http://horwathhtl.com/files/2015/12/MR53 Serbia.pdf, accessed 22/04/2016

[11] Kim, H. B., \& Kim, W. G. (2005). The relationship between brand equity and firms' performance in luxury hotels and chain restaurants. Tourism management, 26(4), 549-560.

[12] Kotas, R. (1982). The European hotel: methodology for analysis of financial operations and identification of appropriate business strategy. International Journal of Hospitality Management, 1(2), 79-84.

[13] Krstic, B., Radivojevic, V., \& Stanisic, T. (2016). Determinants of CEE countries'tourism competitiveness: A benchmarking study. Management, 80, 11-21, DOI: 10.7595/management.fon.2016.0021

[14] Lado-Sestayo, R., Otero-González, L., Vivel-Búa, M., \&Martorell-Cunill, O. (2016). Impact of location on profitability in the Spanish hotel sector. Tourism Management, 52, 405-415.

[15] McManus, L. (2013). Customer accounting and marketing performance measures in the hotel industry: Evidence from Australia. International Journal of Hospitality Management, 33, 140-152.

[16] Milosavljevic, M., Milanovic, N., \&Benkovic, S. (2015). The effects of a systematic governmental measure on tourism development, in proceedings of X SPIN, Belgrade, November 5-6, 2016

[17] Milosavljevic, M., Milanovic, N., \& Benkovic, S. (2016). Drivers of performance measurement use: Empirical evidence from Serbia. Management, 78, 33-43, DOI:10.7595/management.fon.2016.0002.

[18] Morey, R. C., \&Dittman, D. A. (1995). Evaluating a hotel GM's performance: A case study in benchmarking. Cornell Hospitality Quarterly, 36(5), 30.

[19] Mulec, I., \& Wise, N. (2013). Indicating the competitiveness of Serbia's Vojvodina Region as an emerging tourism destination Tourism Management Perspectives, 8, 68-79.

[20] Neirotti, P., Raguseo, E., \&Paolucci, E. (2016). Are customers' reviews creating value in the hospitality industry? Exploring the moderating effects of market positioning. International Journal of Information Management.

[21] Noone, B., \& Griffin, P. (1999). Managing the long-term profit yield from market segments in a hotel environment: a case study on the implementation of customer profitability analysis. International Journal of Hospitality Management, 18(2), 111-128.

[22] Noone, B. M., Kimes, S. E., \& Renaghan, L. M. (2003). Integrating customer relationship management and revenue management: A hotel perspective.Journal of Revenue and Pricing Management,2(1), 721.

[23] O'Neill, J. W., \& Mattila, A. S. (2006). Strategic hotel development and positioning the effects of revenue drivers on profitability. Cornell Hotel and Restaurant Administration Quarterly, 47(2), 146-154.

[24] Pan, C. M. (2005). Market structure and profitability in the international tourist hotel industry. Tourism Management, 26(6), 845-850.

[25] Pan, C. M. (2007). Market demand variations, room capacity, and optimal hotel room rates. International Journal of Hospitality Management,26(3), 748-753.

[26] Phillips, P., Zigan, K., Silva, M. M. S., \&Schegg, R. (2015). The interactive effects of online reviews on the determinants of Swiss hotel performance: A neural network analysis. Tourism Management, 50, $130-141$.

[27] RZS (2015). Statistical Yearbook of the Republic of Serbia, Chapter 16, available at: http://webrzs.stat.gov.rs/WebSite/repository/documents/00/01/88/99/16_Turizam_i_ugostiteljstvo.pdf accessed 22/04/2016

[28] Sainaghi, R., Phillips, P., \& Corti, V. (2013). Measuring hotel performance: Using a balanced scorecard perspectives' approach. International Journal of Hospitality Management, 34, 150-159.

[29] Sheldon, P. J. (1983). The impact of technology on the hotel industry. Tourism Management, 4(4), 269278.

[30] Simicevic, D., \&Stetic, S. (2015). Changes in hotel offer of Belgrade driven by tourist demand. Turistickoposlovanje, 16, 31-41.

[31] Singh, A., \& Dev, C. S. (2015). Winners and Losers during the Great Recession - The Positive Impact of Marketing Expenditures. Cornell Hospitality Quarterly, 56(4), 383-396.

[32] Skuflic, L., \&Mlinaric, D. (2015). Microeconomic determinants of profitability for Croatian hotel industry. Ekonomskipregled: mjesecnikHrvatskogdrustvaekonomista Zagreb, 66, 477-494.

[33] Virginia Phelan, K., Chen, H. T., \& Haney, M. (2013). "Like" and "Check-in": how hotels utilize Facebook as an effective marketing tool. Journal of hospitality and Tourism Technology, 4(2), 134-154.

[34] Zeglat, D. (2008). An investigation of the relationship between service quality and profitability in the UK budget hotel sector (Doctoral dissertation, University of Surrey).

Receieved: November 2016. Accepted: December 2016. 


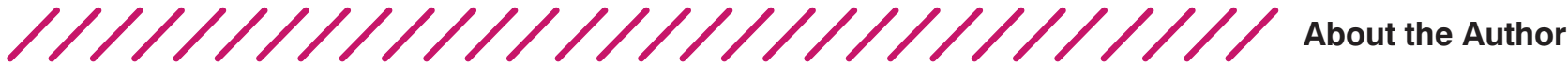

\author{
Miloš Milosavljević \\ University of Belgrade, Faculty of Organizational Sciences, Serbia \\ milosavljevic.milos@fon.bg.ac.rs
}

Ph.D. Miloš Milosavljević is an assistant professor at the University of Belgrade, Faculty of Organizational Sciences. He teaches Financial Management and Management Accounting. He has participated in numerous consulting projects in the field of financial management and controlling. Mr Milosavljević authored or coauthored more than 60 articles and conference papers, text books and international monographs.

\section{Nemanja Milanović \\ University of Belgrade, Faculty of Organizational Sciences, Serbia milanovic.nemanja@fon.bg.ac.rs}

MSc. Nemanja Milanovićis is currently employed as a teaching assistant at the University of Belgrade, Faculty of Organizational Sciences, Department of Financial Management and Accounting. His main fields of research interests are financial management, management accounting and startup funding models. He gained international professional experience through a number of international study and professional exchanges and research projects. He is a member of the European Finance Association and the Youth Committee of the National Petroleum Committee of Serbia - World Petroleum Council.
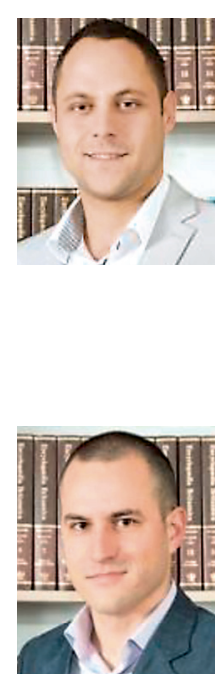

Slađana Benković University of Belgrade, Faculty of Organizational Sciences, Serbia benkovic.sladjana@fon.bg.ac.rs

Ph.D. Slađana Benković is a full professor at the Faculty of Organizational Sciences in Belgrade since 2014. She has participated in numerous projects. During 2007/2009 she spent a period of time at the George Washington University, Washington D.C. as a

research fellow. She is the President of the Management Board of the "Endowment of Milivoje Jovanović and Luka Ćelović", as well as a member of the Management Board of the "Endowment of Đoko Vlajković". Her teaching and research fields are financial management with a research focus on project finance, modalities of financing development projects of companies, technical evaluation of investment profitability and determination of corporate capital structure. 